\title{
МІСЦЕ ТА РОЛЬ САМОСТІЙНӦ̈ РОБОТИ СТУДЕНТА В КРЕДИТНО-МОДУЛЬНІЙ СИСТЕМІ ОРГАНІЗАЦІЇ НАВЧАЛЬНОГО ПРОЦЕСУ
}

\author{
В. М. Ждан, В. М. Бобирьов, О. В. Шешукова, Н. М. Лохматова, Т. В. Шарбенко \\ Виший державний навчальний заклад Украйни \\ “Українська медична стоматологічна академія”, м. Полтава
}

\section{PLACE AND ROLE OF STUDENTS' INDIVIDUAL WORK IN CREDIT-MODULAR ORGANIZATION SYSTEM OF EDUCATIONAL PROCESS}

\author{
V. M. Zhdan, V. M. Bobyryov, O. V. Sheshukova, N. M. Lohmatova, T. V. Sharbenko \\ Higher State Educational Institution of Ukraine \\ “Ukrainian Medical Stomatological Academy”, Poltava
}

\begin{abstract}
Самостійна робота - обов'язковий компонент навчальної та науково-дослідницької роботи студентів, а ї̈ ефективність певною мірою визначає якість професійної підготовки у ВНЗ. Активізація взаємодії викладачів і майбутніх лікарів у процесі навчання позитивно впливає на поліпшення якості підготовки спеціалістів. Це дозволяс оптимально використовувати індивідуальні можливості студентів, виробляє у них наполегливість, організованість, сприяє поглибленню знань, вмінь, розвиває практичні навички, клінічне мислення, виховує необхідність постійного поповнення та розширення обсягу спеціальних знань, орієнтує на систематичну самоосвіту.
\end{abstract}

Individual work is a necessary component of students' educational and scientific work. Its effectiveness determines the quality of professional training at HEE. The activity of interaction between teachers and future doctors at educational process positively influences on a quality of specialists' training. It allows to use the individual students abilities, produces persistence, good organization, promotes deep knowledge, skills, develops practical skills, clinical thought, educates the necessity of permanent enriching and expansion of special knowledge volume, orients on systemic self-education.

Вступ. В умовах реформування вищої школи серед питань, що постають перед науково-педагогічними колективами, особливо великого значення набуває розробка основ педагогіки співробітництва, яка базується на принципі спільної творчої діяльності того, хто навчає, і того, хто навчається. Сучасні умови диктують самоцінність ідеї неперервної освіти, коли від студентів вимагається постійне удосконалення власних знань $[1,2]$. В умовах інформаційного суспільства відбувається принципова зміна організації освітнього процесу: скорочення аудиторного навантаження, заміна пасивного слухання лекцій зростанням частки самостійної роботи студентів. Розглядаючи шляхи активізації взаємодії викладача і студентів у навчально-виховному процесі доцільно проаналізувати таку важливу його частину, як самостійна робота. У процесі становлення професійних, моральних, особистісних якостей майбутнього лікаря, а тим більш лікаря-стоматолога, самостійна робота набуває особливої ролі. Тому організації самостійної роботи приділяється значна увага з боку адміністрації Вищого державного навчального закладу України "Українська медична стоматологічна академія".

Основна частина. Удосконалення вміння самостійно приймати рішення, відповідаючи не тільки за якість своєї роботи, а і за здоров'я пацієнта, “шліфовка" мануальних навичок, комунікативних здібностей відбувається завдяки наполегливій самостійній роботі, яку слід розглядати як взаємопов'язану та взаємозалежну діяльність викладача і майбутнього лікаря.

Залежно від місця і часу проведення самостійної роботи студентів, характеру керування нею з боку викладача і способу контролю за ії результатами роз-

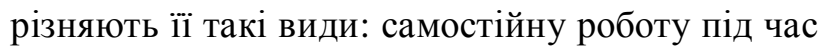
основних аудиторних занять (лекцій, семінарів, практичних занять), самостійну роботу під контролем

(c) В. М. Ждан, В. М. Бобирьов, О. В. Шешукова, та ін. 
викладача у формі планових консультацій, виробничої практики, заліків та іспитів та позааудиторну самостійну роботу при виконанні студентом домашніх завдань навчального і творчого характеру. Таким чином, самостійну роботу студентів структурно можна розділити на дві частини: організовану викладачем і самостійну роботу, що студент будує за своїм розсудом, без безпосереднього контролю з боку викладача (підготовка до лекцій, семінарів, клінічних конференцій, практичних занять, заліків, іспитів тощо). Керування самостійною роботою студентів з боку викладача - це, насамперед, уміння оптимізувати процес сполучення цих двох частин.

Зміст організованої самостійної роботи студентів описаний в робочій програмі кожної дисципліни і спрямований на розширення і поглиблення знань за даним курсом, а на старших курсах - також на засвоєння міжпредметних зв' язків. Час на їі виконання не повинен перевищувати норм, відведених навчальним планом на самостійну роботуз даної дисципліни. У зв' язку з цим необхідно ще на стадії розробки навчальних планів, призначаючи обсяги часу, враховувати форму організованої самостійної роботи студентів.

Основні форми організації самостійної роботи студентів визначаються такими параметрами: зміст навчальної дисципліни; рівень освіти і ступінь підготовленості студентів; необхідність упорядкування навантаження студентів при самостійній роботі [6]. Виходячи з цих параметрів, можуть бути запропоновані такі форми організації самостійної роботи студентів: реферати та доповіді (з дисциплін гуманітарного і соціально-економічного блоку); огляди літератури, навчальні історії хвороби, ведення зошитів та альбомів із самопідготовки, бесіди із санітарно-просвітницької роботи, доповіді на студентських конференціях, атестаційні роботи (наприклад, на ступінь магістра). Форму організації самостійної роботи студентів пропонують кафедри, розробляючи робочі програми дисциплін. При цьому вони можуть встановити й інші форми, не зазначені вище, якщо з ними погоджується центральна методична комісія академії.

Ефективна реалізація самостійної роботи залежить від зацікавленості в досягненні результату, тобто від стійкої мотивації $[3,4]$. Основні види мотивації самостійної роботи студентів: 1. Зовнішня мотивація залежність професійної кар'єри від результатів навчання у вузі. 2. Внутрішня мотивація - схильність студента, його здатність до навчання у вузі. Нею можна керувати в період довузівської підготовки шляхом використання тестів при виборі спеціальності, обгрунтованої рекомендації при визначенні напрямку освіти. 3. Процесуальна (навчальна) мотивація виявляється в розумінні студентом корисності виконуваної роботи. Потрібний психологічний настрій студента на важливість цієї роботи як у плані професійної підготовки, так і в плані розширення кругозору, ерудиції фахівця. Необхідно переконливо показати (довести), що результати самостійної роботи допоможуть йому краще зрозуміти лекційний матеріал, досягти успіху в практичній роботі.

Контроль самостійної роботи студентів не повинен бути самоціллю для викладача, а насамперед - стати мотивуючим фактором освітньої діяльності студента. Варто включати результати виконання самостійної роботи у показники поточної успішності, від оцінок яких залежить рейтинг студента, остаточна оцінка, а отже, стипендія чи їі розмір. Багатьом студентам важливий моральний інтерес у формі суспільного визнання. При цьому важливо прагнути до того, щоб на молодших курсах самостійна робота ставила за мету розширення і закріплення знань і умінь, що здобуваються студентом на традиційних формах занять. На старших курсах самостійна робота повинна сприяти розвитку творчого потенціалу студента. Для ефективності самостійної роботи необхідно виконати ряд умов. Головними умовами є забезпечення правильного сполучення об' єму аудиторної і самостійної роботи. Велику роль тут відіграє правильне визначення трудомісткості різних видів самостійних робіт. Складанню такого плану повинне передувати серйозне вивчення бюджету часу студента та оснащеності методичною літературою.

Відіграє роль і методично правильна організація роботи студента в аудиторії і поза нею. Якщо на перших курсах викладачу належить активна творча позиція, то в міру просування до старших курсів ця послідовність повинна реформуватися в бік спонукання студента працювати самостійно, активно прагнути до самоосвіти.

Важливим є забезпечення студента необхідними методичними матеріалами з метою перетворення процесу самостійної роботи в процес творчий. 3 огляду на економічні умови і можливості поліграфічної бази, варто рекомендувати перехід на електронні видання, лекційні матеріали викладачів, що зараз уже частково реалізується. Особливо варто виділити, як можливість забезпечення навчальною і методичною літературою, дистанційне навчання з використанням інформаційних комп'ютерних технологій, зокрема, комп'ютерних освітніх середовищ, спеціально побудованих і організованих для розміщення навчальних матеріалів з обліком педагогічних і дидактичних ви- 
мог. Саме дистанційне навчання покликане скоротити аудиторне навантаження й збільшити частку самостійної роботи студента [5].

Методично правильний контроль за організацією і ходом самостійної роботи заохочує студента якісно ii виконувати. Ця умова в той чи іншій формі з необхідністю повинна бути присутньою у перших трьох, щоб контроль став не стільки адміністративною, скільки саме повноправною дидактичною умовою, що позитивно впливає на ефективність самостійної роботи у цілому.

Великого значення для опанування студентами навичок самостійної роботи набувають зміст та методи організації практичних занять, особливо за наявності в них елементів наукових досліджень. На таких заняттях керівництво самостійною роботою студентів здійснюється в процесі співпраці викладача і студента і має на меті сформувати в останнього вміння будувати і використовувати алгоритм розв'язання ситуаційних завдань, самостійно працювати 3 навчальною та довідковою літературою, аналізувати матеріали лекцій.

Однією з форм самостійної роботи в навчальному процесі $є$ клінічний розгляд тематичних хворих. Студенти виконують роль не пасивних спостерігачів, а самостійно, докладно, з урахуванням особливостей деонтології, доповідають скарги, анамнез, особливості клінічного перебігу, проводять огляд, намічають план обстеження, обгрунтовано формулюють клінічний діагноз, планують лікування з урахуванням віку. Таким чином, заняття проводиться з максималь-

\section{Література}

1. Алексюк А. М. Педагогіка вищої освіти України. Історія. Теорія : підручник/А. М. Алексюк. -К. : Либідь, 1998.-560с.

2. Болюбаш Я. Я. Організація навчального процесу у вищих закладах освіти / Я. Я. Болюбаш. - К. : Наукова думка, 1997.-С. 62.

3. Бондар В. І. Дидактика : ефективні технології навчання студентів / В. І. Бондар. - К. : Вересень, 1996. - 129 с.

4. Вакуленко В. М. Основи вищої школи України : навчальний посібник / В. М. Вакуленко. - Луганськ : Вид-во CHУ, 2001.-247 c. ною активізацією пізнавально-розумової діяльності студентів. Розгляд закінчується вирішенням ситуаційних завдань, що вчить гнучкості використання отриманих знань, вміння орієнтуватися у нових нестандартних ситуаціях, поєднувати теорію з практикою.

Однією з форм активізації взаємодії викладачів та студентів у самостійній роботі $є$ підготовка наукової роботи та доповідь на науково-практичній конференції. Науково-дослідницька робота має неабияке значення як в плані підвищення професійних знань та навичок майбутнього лікаря, так і для формування культурно розвинутої особистості. Важливе значення має і опанування прийомів національного офіційно-ділового і наукового стилю мовлення. Усе це сприяє виникненню зацікавленості проблемами медичної науки, формуванню багатогранної особистості лікаряспеціаліста.

Висновок. Таким чином, самостійна робота обов'язковий компонент навчальної та науково-дослідницької роботи студентів, а ії ефективність значною мірою визначає якість професійної підготовки у ВНЗ. Активізація взаємодії викладачів і майбутніх лікарів у процесі навчання позитивно впливає на поліпшення якості підготовки спеціалістів. Це дозволяє оптимально використовувати індивідуальні можливості студентів, виробляє уних наполегливість, організованість, сприяє поглибленню знань, вмінь, розвиває практичні навички, клінічне мислення, виховує необхідність постійного поповнення та розширення обсягу спеціальних знань, орієнтує на систематичну самоосвіту.

5. Дидора Т. Д. Организация и дидактическое обеспечение дистанционной формы обучения в вузе / Т. Д. Дидора, С. В. Мохун, В. В. Иванко// Образовательные технологии. 2010. - № 2. - С. 36-52.

6. Філіпенко А. С. Основи наукових досліджень : конспект лекцій : навч. посібник / А. С. Філіпенко. -К. : Академвидав, 2004. - 208 c. 